\title{
PENINGKATAN KINERJA GURU MELALUI SUPERVISI EDUKATIF SEMESTER I SD NEGERI DOMBO 1 KECAMATAN SAYUNG KABUPATEN DEMAK TAHUN PELAJARAN 2021/2022
}

\author{
REJO \\ SD Negeri Dombo 1 Kecamatan Sayung Kabupaten Demak \\ e-mail: rejo1166@gmail.com
}

\begin{abstract}
ABSTRAK
Penelitian ini bertujuan ingin Meningkatakan Kinerja Guru SD Negei Dombo 1 melalui supervisi edukatif. Mendeskripsikan langkah-langkah supervisi edukatif kolaboratif secara periodik dalam menyusun Rencana Pelaksanaan pembelajaran, melaksanakan pembelajaran, menilai prestasi belajar, melaksanakan tindak lanjut penilaian prestasi belajar siswa yang dapat meningkatkan kinerja guru. Peningkatan kinerja ini melalui supervisi edukatif kolaboratif secara periodik. Penelitian tindakan Sekolah ini dilakukan terhadap guru SD Negeri Dombo 1, Kecamatan Sayung Kabupaten Demak yang berjumlah 16 orang. Penelitian tindakan dilaksanakan mulai bulan September 2021 sampai dengan November 2021. Rancangan penelitian yang digunakan adalah rancangan penelitian tindakan (reserch) yang alurnya: membuat rencana tindakan, melaksankan tindakan, dan refleksi pelaksanaan tindakan. Hasil refleksi tersebut digunakan sebagai pedoman untuk pengambilan keputusan melanjutkan atau menghentikan penelitian. Penelitian dilakukan secara spiral dalam siklus-siklus sampai siklus kedua. Data penelitian berupa catatan hasil pengamatan, catatan lapangan, dokumentasi perencanaan dan hasil supervisi. Instrumen pengumpul data utama adalah peneliti, sedangkan instrument penunjangnya adalah pedoman observasi, dokumentasi. Analisis data dilakukan dengan teknik kualitatif dan kuantitatif. Hasil penelitian menunjukkan bahwa kinerja guru meningkat setelah dilakukan tindakan yang berupa supervisi edukatif secara langsung dari siklus I ke siklus II. Peningkatan tersebut meliputi peningkatan dalam menyusun rencana pembelajaran, melaksanakan pembelajaran, menilai prestasi belajar, melaksanakan tindak lanjut penilaian prestasi belajar siswa. Berdasarkan hasil penelitian tindakan tersebut dapat disimpulkan bahwa kinerja guru meningkat dalam menyusun rencana pembelajaran, melaksanakan pembelajaran, menilai prestasi belajar, melaksanakan tindak lanjut penilaian prestasi belajar siswa. Untuk itu, peneliti menyarankan agar di sekolah-sekolah melaksanakan supervisi edukatif.
\end{abstract}

Kata kunci : Kinerja, kepala sekolah, supervisi edukatif

\section{ABSTRACT}

This study aims to 1) Improve Teacher Performance at SD Negeri Dombo 1 through educational supervision. 2) Describe the steps of collaborative educational supervisionperiodically in preparing learning implementation plans, implementing learning, assessing learning achievement, carrying out follow-up assessments of student achievement that can improve teacher performance. This performance improvement is carried out through periodic collaborative educational supervision. This action research was conducted on 16 teachers of SD Negeri Dombo 1, Sayung District, Demak Regency. The action research was carried out from September 2021 to November 2021. The research design used is an action research design (reserch) whose flow is: making an action plan, implementing the action, and reflecting on the implementation of the action. The results of these reflections are used as guidelines for making decisions to continue or stop the research. The research was carried out in a spiral in cycles until the second cycle. The research data are in the form of observation notes, field notes, planning documentation and supervision results. The main data collection instrument is the researcher, while the supporting instruments are observation and documentation guidelines. Data analysis was carried out using qualitative and quantitative techniques. The results showed that the teacher's performance increased after the action in the form of direct educative 
supervision was carried out from cycle I to cycle II. These improvements include improvements in preparing lesson plans, implementing learning, assessing learning achievement, carrying out follow-up assessments of student achievement Based on the results of educative supervision in cycle I and cycle II, teacher performance increased, namely in cycle I, teacher performance in preparing learning plans for cycle I reached $76 \%$, while in cycle II it was $91 \%$. The teacher's performance in implementing the learning cycle I reached $71 \%$ while the second cycle reached $89 \%$. Teacher performance in assessing learning achievement in the first cycle reached $70 \%$ while the second cycle was $90 \%$. Teacher performance in carrying out follow-up assessments of student achievement in the first cycle reached $54 \%$ while the second cycle was $84 \%$. Thus, the average cycle II action was already above $75 \%$. Based on the results of the action research, it can be concluded that the teacher's performance increases in preparing lesson plans, implementing learning, assessing learning achievement, carrying out follow-up assessments of student achievement. For this reason, researchers suggest that schools carry out educational supervision.

Keywords: Performance, principal, educative supervision

\section{PENDAHULUAN}

Kinerja guru atau prestasi kerja adalah suatu hasil kerja yang dicapai seseorang dalam melaksanakan tugas-tugas yang dibebankan kepadanya yang didasarkan atas kecakapan, pengalaman, dan kesungguhan serta waktu (Hasibuan, 2001:94). Kinerja guru akan baik jika guru telah melakukan unsur-unsur yang terdiri dari kesetiaan dan komitmen yang tinggi pada tugas mengajar, menguasai dan mengembangkan bahan pelajaran, kedisiplinan dalam mengajar dan tugas lainnya, kreativitas dalam pelaksanaan pengajaran, kerjasama dengan semua warga sekolah, kepemimpinan yang menjadi panutan siswa, kepribadian yang baik, jujur dan objektif dalam membimbing siswa, serta tanggung jawab terhadap tugasnya. Oleh karena itu tugas kepala sekolah selaku manager adalah melakukan penilaian terhadap kinerja guru.

Ada beberapa hal yang menyebabkan meningkatnya kinerja guru, namun penulis mencoba mengkaji masalah supervisi yang diberikan oleh kepala sekolah. Supervisi dalam hal ini adalah mengenai tanggapan guru terhadap pelaksanaan pembinaan dan bimbingan yang diberikan oleh kepala sekolah yang nantinya berdampak kepada kinerja guru yaitu kualitas pengajaran. Supervisi pendidikan didefinisikan sebagai proses pemberian layanan bantuan profesional kepada guru untuk meningkatkan kemampuannya dalam melaksanakan tugas-tugas pengelolaan proses pembelajaran secara efektif dan efisien (Bafadal, 2004:46). Dengan adanya pelaksanaan supervisi oleh kepala sekolah diharapkan memberi dampak terhadap terbentuknya sikap professional guru.

Kegiatan supervisi kepala sekolah akan berpengaruh secara psikologis terhadap kinerja guru, guru yang puas dengan pemberian supervisi kepala sekolah dan motivasi kerjanya tinggi maka ia akan bekerja dengan sukarela yang akhirnya dapat membuat produktivitas kerja guru meningkat. Tetapi jika guru kurang puas terhadap pelaksanaan supervisi kepala sekolah dan motivasi kerjanya rendah maka guru dalam bekerja kurang bergairah, hal ini mengakibatkan produktivitas guru menurun.

Selama ini Kinerja Guru SD Negeri Dombo 1 Kurang begitu maksimal yang antara lain diantaranya sebagai berikut: Dalam kehadiran di sekolah masih banyak guru yang mengalami keterlambatan.Dalam menyusun perangkat pembelajara ( Promes, Silabus, RPP ) cenderung guru hanya copy paste dari internet tanpa di edit atau dari penerbit LKS tertentu.Guru tidak melakukan analisis hasil ulangan dimungkinkan karena tidak mampu memanfaatkan waktu yang tersedia.Dalam kegiatan supervisi yang dilakukan kepala sekolah dianggap hal yang membebankan guru.Untuk memperbaiki kinerja dan wawasan guru dalam pembelajaran di SD Negeri Dombo 1, peneliti selaku Kepala Sekolah melaksanakan penelitian tindakan yang berkaitan dengan permasalahan di atas. Bertitik tolak dari latar belakang di atas maka penulis tertarik untuk mengadakan penelitian dengan judul "Peningkatan Kinerja Guru Melalui 
Supervisi Edukatif Semester I SD Negeri Dombo 1 Kecamatan Sayung Kabupaten Demak Tahun Pelajaran 2021 / 2022 ".

Berkaitan dengan kinerja yang dilakukan guru dalam proses belajar perlu adanya peningkatan dan perbaikan kinerja dalam pembelajaran dengan menggunakan Supervisi Edukatif. Supervisi edukatif merupakan supervisi yang diarahkan pada kurikulum pembelajaran, proses belajar mengajar, pelaksanaan bimbingan dan konseling, (Imran, 2018;Desmaini, 2019; Masrayati, 2019). Supervisi ini dapat dilakukan oleh pengawas, kepala sekolah, maupun guru senior yang sudah pernah menjadi instruktur mata pelajaran Pelaksanaan supervisi yang dilakukan oleh kepala sekolah terhadap guru dapat berupa wawancara, observasi, maupun berdasarkan portofolio dalam proses belajar mengajar atau dalam kegiatan bimbingan dan konseling guru (Jokomarsono, 2019). Menurut Dirjen Dikmenum (1884:16) dalam Imran (2018) observasi tersebut bisa berupa: (1) Observasi kegiatan belajar mengajar meliputi: (a) persiapan mengajar, (b) pelaksanaan satuan pelajaran di dalam kelas, dan (c) pelaksanaan penilaian. (2) Observasi kegiatan Bimbingan dan konseling meliputi: (a) program kegiatan bimbingan dan konseling di sekolah, (b) pelaksanaan bimbingan dan konseling di sekolah, (c) kelengkapan administrasi/ perlengkapan Bimbingan dan Konseling, (d) penilaian dan laporan

Langkah-langkah yang dapat meningkatkan kinerja guru di SDN Dombo 1 dalam membuat persiapan pembelajaran adalah: memberikan format supervisi dan jadwal supervisi, menanyakan perkembangan pembuatan perangkat pembelajaran, dan pelaksanaan supervisi perangkat pembelajaran, menanyakan format penilaian, meminta pengumpulan perangkat pembelajaran yang sudah dibuatnya untuk diteliti kelebihan dan kekurangannya. Memberikan catatan-catatan khusus pada lembaran untuk diberikan kepada guru yang akan disupervisi tersebut. Peneliti yang mengamati guru mengajar tidak sebagai penilai tetapi sebagai rekan kerja yang siap membantu guru tersebut. Selama pelaksanaan supervisi di kelas guru tidak menganggap peneliti sebagai penilai karena sebelum pelaksanaan supervisi guru dan peneliti telah berdiskusi permasalahan-permasalahan yang ada dalam pembelajaran tersebut. Peneliti mencatat semua peristiwa yang terjadi di dalam pembelajaran baik yang positif maupun yang negatif, dan selalu memberi contoh pembelajaran yang berorientasi pada modern learning. Pelaksanaan supervisi edukatif secara periodik memberikan dampak positif terhadap guru dalam menyusun soal/perangkat penilaian, melaksanakan, memeriksa, menilai, mengolah. Kemudian menganalisis, menyimpulkan, menyusun laporan dan memperbaiki soal. Melaksanakan tindak lanjut hasil penilaian prestasi belajar peserta didik, dalam menyusun program pembelajaran, melaksanakan pembelajaran, menilai prestasi belajar, dan melaksanakan tindak lanjut hasil prestasi belajar siswa. Supervisi edukatif merupakan supervisi yang diarahkan pada kurikulum pembelajaran, proses belajar mengajar, pelaksanaan bimbingan dan konseling. Hal yang didiskusikan meliputi: kesesuaian pembelajaran dengan perencanaan, materi yang digunakan pembelajaran, evaluasi pembelajaran, kesesuaian tindakan guru dengan format supervisi, dan tindak lanjut.

Dengan adanya supervisi edukatif ini akan menumbuhkan pengaruh positif terhadap perbaikan kualitas kinerja guru. Kinerja guru adalah tingkat ketercapainnya tujuan yang sudah diprogramkan / keberhasilan yang diperoleh oleh guru dalam mencapai tujuan pembelajaran. kinerja adalah peningkatan pencapain seseorang dalam saat tertentu (Moeheriono, 2009 dalam Rasto, 2016).

Kinerja guru memiliki spesifikasi tertentu, serta dapat diukur dengan indikator tertentu. Menurut Uno dan Lamatenggo, 2012 dalam Rasto, (2016) merumuskan lima indicator untik mengukur kinerja guru antara lain :1. Kualitas kerja. Indikator ini berkaitan dengan kualitas kerja guru dalam menguasai segala sesuatu berkaitan dengan persiapan perencanaan program pembelajaran dan penerapan hasil penelitian dalam pembelajaran di kelas. 2. Ketetapan kerja. Indikator ini berkaitan dengan ketepatan kerja guru dalam menyesuaikan materi ajar dengan karakteristik yang dimiliki peserta didik dan penyelesaian program pengajaran sesuai dengan kalender akademik. 3. Inisiatif dalam kerja. Indikator ini berkaitan dengan inisiatif guru dalam 
penggunaan model pembelajaran yang variatif sesuai materi pelajaran dan penggunaan berbagai inventaris sekolah dengan bijak. 4. Kemampuan kerja. Indikator ini berkaitan dengan kemampuan guru dalam memimpin keadaan kelas agar tetap kondusif, pengelolaan kegiatan belajar mengajar, dan penilaian hasil belajar peserta didik. Dan 5. Komunikasi. Indikator ini berkaitan dengan komunikasi yang dilakukan guru dalam proses layanan bimbingan belajar dengan siswa yang kurang mampu mengikuti pembelajaran dan terbuka dalam menerima masukan untuk perbaikan pembelajaran

Berdasarkan refleksi dan diskusi dengan teman sejawat selaku supervisor dapatdii dentifikasi berbagai masalah yang muncul adalah sebagai berikut: Penerapan supervisi disekolah terhadap guru belum dilaksanakan secara nmaksimal.Kemampuan guru masih rendah dilihat dari kwalitas RPP yang dibuat guru. Guru kurang maksimal dalam menyusun evaluasi belajar. Analisis hasil ulangan yang dilakukan guru tidak dilakukan secara rutin.. Dari identifikasi masalah diatas dapat dianalisa beberapa masalah yang timbul adalah:Dalam kegiatan supervisi yang dilakukan kepala sekolah dianggap hal yang membebankan guru Dalam menyusun RPP cenderung guru hanya copy paste dari internet tanpa di edit 3. Guru tidak melakukan analisis hasil ulangan dimungkinkan karena tidak mampu memanfaatkan waktu yang tersedia. Dari identifikasi masalah dan analisa masalah diatas dapat peneliti temukan beberapaalternatif pemacahan masalahnya antara lain: 1.Perlu dilakukan supervisi secara periodik untuk meningkatkan kinerja guru 2.Perlu memberikan pelatihan trhadap guru dalam menyusun RPP.3.Perlu memberi contoh langsung terhadap guru RPP yang baik. 4 Pelu diadakan pelatihan dalam menyusun analisis hasil ulangan siswaDari berbagai alternatif pemecahan maslah diatas peneliti selaku Kepala Sekolah di SD Negeri Dombo 1, memfokuskan pemecahan masalahnya pada: Peningkatan Kinerja Guru Melalui Supervisi Edukatif Semester I SDN Dombo 1 Kecamatan Sayung Kabupaten Demak Tahun Pelajaran 2021/ 2022.

\section{METODE PEELITIAN}

Penelitian yang dilakukan adalah penelitian tindakan (action research) yang bertujuan untuk Peningkatkan kinerja guru SD Negeri Dombo 1,Sayung, Demak. Tindakan yang akan dilakukan adalah Supervisi Edukatif. Subjek penelitian ini Para Guru di SD Negeri Dombo 1 Sayung, Demak Sejumlah 16 orang, yang terdiri atas: 8 orang guru laki-laki dan 8 orang guru perempuan. Sedangkan yang menjadi objek penelitian adalah kinerja Guru SD Negeri Dombo 1. Penelitian dilakukan pada seluruh guru SD Negeri Dombo 1, Sayung, Demak pada semester I Tahun Pelajaran 2021/2022. Pemilihan lokasi penelitian di sekolah tersebut karena sekolah itu merupakan tempat peneliti sebagai kepala sekolah. Di samping itu, dari hasil supervisi kepala sekolah ditemukan bahwa Kinerja Guru SD Negeri Dombo 1 masih terdapat beberapa kelemahan..

\section{HASIL DAN PEMBAHASAN}

\section{Hasil Penelitian}

Berdasarkan pemantauan Peneliti selama persiapan, pelaksanaan, dan tindak lanjut penelitian tindakan ini diperoleh berbagai data baik dari guru yang sedang melaksanakan proses belajar mengajar, siswa yang belajar, supervisor yang sedang melaksanakan supervisisnya. Gambaran yang merupakan hasil dan temuan penelitian sebagai berikut

Dalam Perencanaan Supervisi Siklus I Peneliti bersama suprvisor selaku teman sejawat membuat perencanaan yang berkaitan dengan pembuatan instrumen penelitian. Instrumen tersebut dibuat berdasarkan pada indikator yang dibuat oleh Departemen Pendidikan Nasional. Hasil pemantauan sebagai berikut. Pembuatan format penilaian pra-KBM sebagai berikut. Mendeskripsikan tujuan pembelajaran Menentukan materi sesuai dengan kompetensi yang telah ditentukan mengorganisasikan materi berdasarkan urutan dan kelompok mengalokasikan waktu Menentukan metode pembelajaran yang sesuai Merancang prosedur pembelajaran Menentukan media pembelajaran/peralatan praktikum (dan bahan) yang akan digunakan 
menentukan sumber belajar yang sesuai (berupa buku, modul, program komputer dan sejenisnya) menentukan teknik penilaian.

Berdasarkan instrumen tersebut, guru akhirnya membuat perencanaan pembelajaran yang alurnya sama dengan instrumen supervisi tersbut. Berdasarkan data yang dikumpulkan, ternyata hampir semua guru dapat membuat perencanaan tersebut, tetapi hasilnya jika kita ukur dengan indikator yang telah ditetapkan masih ada yang kurang.

Dalam Pelaksanaan Supervisi Siklus Iinstrumen penelitian yang digunakan berupa instrumen yang sesuai dengan indikator yang dibuat oleh Depdiknas, yakni: Membuka pelajaran dengan metode yang sesuai Menyajikan materi pelajaran secara otomatis Menerapkan metode dan prosedur pembelajaran yang telah ditentukan Mengatur kegiatan siswa di kelas Menggunakan media pembelajaranyang telah ditentukan Menggunakan sumber belajar yang telah dipilih (berupa buku, modul, program komputer dan sejenisnya) Memotivasi siswa secara positif Melakukan interaksi dengan siswa menggunakan bahasa yang komunikatif Memberikan pertanyaan dan umpan balik, untuk mengetahui dan memperkuat penerimaan siswa dalam belajar Menyimpulkan pembelajaran Menggunakan waktu secara efektif dan efisien

Saat Penilaian Supervisi Siklus I Instrumen penilaian yang digunakan dalam penelitian tindakan berupa instrumen yang sesuai dengan indikator yang dibuat oleh Depdiknas, yakni: Menyusun dan Melaksanakan penilaian sesuai dengan kriteria unjuk kerja yang telah ditentukan Memeriksa dan memberikan skor tes hasil belajar berdasarkan kriteria unjuk kerja yang telah ditentukan Mengolah hasil penilaian Menganalisis hasil penilaian (berdasarkan tingkat kesukaran, daya pembeda, validitas dan reabilitas) Menyimpulkan hasil penilaian secara jelas dan logis Menyusun laporan hasil penilaian Memperbaiki soal/perangkat penilaian.

Dalam Pelaksanakan Tindak Lanjut Hasil Penilaian Siklus I Kegiatan ini dilaksanakan oleh guru pada bagian terakhir setelah melaksanakan penilaian dengan tujuan menganalisis program penilaian dan perbaikan hasil penilaian. Adapun instrumen yang digunakan untuk menjaring data berupa indikator yang dibuat oleh Depdiknas (2004:12) yaitu: Mengidentifikasi kebutuhan tindak lanjut hasil penilaian Menyusun program tindak lanjut hasil penilaian Melaksanakan tindak lanjut Mengevaluasi hasil tindak lanjut hasil penilaian Menganalisis hasil evaluasi program tindak lanjut hasil penilaian

Tindakan Supervisor Siklus I pada pelaksanaan supervisi siklus I sebagai berikut. Supervisor memeberikan indikator yang harus dicapai pada saat persiapan, pelaksanaan, dan penilaian seminggu sebelum pelaksanaan supervisi, Supervisor menyuruh guru mengisi format penilaian serta membuat perencanaan kembali kegiatan berikut yang akan disupervisi

Refleksi Siklus I Perencanaan Supervisi Siklus I (merencanakan KBM), Setelah dilaksanakan diskusi dengan guru kelas dan guru mata pelajaran dan supervisor maka peneliti menulis hasil refleksi sebagai berikut. Mendeskripsikan tujuan pembelajaran 12 guru dari 16 guru dengan presentasi $75 \%$, berhasil berdasarkan data tersebut kegiatan guru sudah baik. Kegiatan seperti itu dipertahankan, tetapi ada dua guru yang perlu dimotivasi. Menentukan materi sesuai dengan kompetensi yang telah ditentukan sebanyak 12 guru dari 16 guru dengan presentasi $75 \%$, berdasarkan data itu kegiatan guru tersebut ditigkatkan dan ada dua guru yang masih perlu pembekalan pengetahuan.Mengorganisasikan materi berdasarkan urutan dan kelompok sebanyak 14 guru dar 16 guru dengan presentasi 87,5\%. Pada bagian ini guru perlu dipertahankan dan masih ada satu guru yang perlu bimbingan. Mengalokasikan waktu sebanyak 12 guru dari 16 guru dengan presentasi $75 \%$. Kegiatan pada bagian ini perlu ditingkatkan melalui pelatihan, yakni menentukan aloksi waktu melalui workshop singkat guru kelas dan mata pelajaran di sekolah dengan dipandu guru senior. Menentukan metode pembelajaran yang sesuai sebanyak 14 guru dari 16 guru dengan presentasi $87,5 \%$, berdasarkan catatan dan hasil pelaksanaan perlu dipertahankan walau ada dua guru yang masih perlu bimbingan dalam menentukan metode. Merancang prosedur pembelajaran sebanyak 12 guru dengan presentasi $75 \%$. Pada penentuan prosedur sangat berkaitan dengan metode pembelajaran. Oleh sebab itu, perlu ada perbaikan di bidang ini karena ada empat guru yang belum maksimal. Guru masih terpancang dengan prosedur-prosedur yang sifatnya mengancam siswa jika kurang mampu atau 
melanggar pembelajaran. Menentukan media pembelajaran/peralatan praktikum (dan bahan) yang akan digunakan sebanyak 12 guru dengan presentasi $75 \%$. Guru pada bagian ini masih terfokus pada media yang dibeli atau dibuat oleh perusahaan padahal di sekitar kelas banyak media alami yang bisa digunakan sebagai media. Bagian ini, masih 4 guru perlu diperbaiki. Menentukan sumber belajar yang sesuai (berupa buku, modul, program komputer dan sejenisnya) sebanyak 12 guru dengan presentasi $75 \%$, masih ada dua guru yang kesulitan menentukan buku sumber karena, keterbatasan kesediaan buku Bhs Inggris. Menentukan teknik penilaian sebanyak 12 guru dengan presentasi $75 \%$. Teknik-teknik yang dibuat guru dalam menyusun penilaian masih kurang beragam. Guru masih terfokus pada teknik tradisional yakni penilaian hasil saja, padahal kita juga perlu penilaian proses hasil ,pada tahap perencanaan pembelajaran pada siklus I capaian rata-rata keberhasilan guru mencapai $76 \%$.

Refleksi Pelaksanaan Pembelajaran Supervisi Siklus I Hasil refleksi pada bagian pelaksanaan supervisi dan setelah diadakan diskusi dengan guru, peneliti, dan supervisor sebagai berikut. Membuka pelajaran dengan metode yang sesuai. Guru rata-rata sudah mampu membuka pelajaran dengan metode yang tepat. Guru yang dianggap mampu membuka pelajaran dengan tepat sebanyak 12 orang dari 16 guru atau dengan persentasi $75 \%$.(kategori berhasil) Berdasarkan persentasi di atas, guru perlu mempertahankan cara tersebut. Adapun 4 guru yang belum sesuai perlu diajak diskusi bersama dengan supervisor, dan guru senior. Menyajikan materi pelajaran. Dalam menyajikan materi pelajaran, guru rata-rata sudah baik dan berdasarkan pengamatan ada 12 guru dari 16 guru yang dikategorikan baik. Jika hal itu dipersentasi maka sudah mencapai $75 \%$.(berhasil). Menerapkan metode dan prosedur pembelajaran yang telah ditentukan berjumlah 12 guru dari 16 guru dengan persentasi $75 \%$. Kategori berhasil. Sebagai perbaikan guru-guru yang masih belum paham dalam menggunakan metode pembelajaran yang modern diwajibkan membaca buku-buku yang berkaitan metode pembelajaran modern, terutama buku CTL, dan diberi contoh pembelajaran modern.

Mengatur kegiatan siswa di kelas berjumlah 12 guru dengan persentasi $75 \%$ kategori berhasil. Guru yang belum berhasil mengelola kelas ada 4 guru perlu diajak diskusi pada pasca supervisi. Menggunakan media pembelajaran/ peralatan praktikum (dan bahan) yang telah ditentukan berjumlah 12 guru dengan persentasi $75 \%$ kategori baik. Menggunakan sumber belajar yang telah dipilih (berupa buku, modul, program komputer dan sejenisnya) berjumlah 12 guru dengan persentasi 75\%. Kategori baik. Tetapi, kepala sekolah, supervisor harus terus memotivasi guru-guru tersebut karena ada 4 guru yang kesulitan dengan sumber belajar. Memotivasi siswa dengan berbagai cara yang positif, berjumlah 10 guru dengan persentasi 62,5 $\%$. Kategori cukup artinya masih ada 6 guru $(37,5 \%)$ yang kurang memotivasi siswa. jarang memberi motivasi pada siswa rata-rata guru senior. Hal ini terjadi karena masih terpengaruh pada pendidikan lama.. Melakukan interaksi dengan siswa menggunakan bahasa yang komunikatif berjumlah 10 guru dengan persentasi 62,5\%. Ada 6 guru yang masih menggunakan bahasa yang sulit dipahami siswa. Hal itu terjadi pada guru yunior. Memberikan pertanyaan dan umpan balik, untuk mengetahui penerimaan siswa dalam proses belajar berjumlah 10 guru dengan persentasi 62,5\%. Guru masih jarang memberi umpan balik pada siswa. Menyimpulkan pembelajaran berjumlah 10 guru dengan persentasi 62,5\%. Guru masih ada yang belum menyimpulkan pembelajaran. Hal ini terjadi karena waktunya habis digunakan mengerjakan LKS saja. Untuk itu perlu disesuaikan soal-soal yang dikerjakan dalam LKS itu. Menggunakan waktu secara efektif dan efisien berjumlah 10 guru dengan persentasi 62,5\%.Guru kurang efektif dalam menggunakan waktu pembelajaran jika dikaitkan dengan langkah-langkah yang ada dalam indikator tersebut karena waktunya hanya tersita pada mengerjakan LKS saja. Rata-rata keberhasilan pelaksanaan KBM pada siklus I para guru adalah mencapai $71 \%$,

Refleksi Penilaian Supervisi Siklus I Hasil refleksi pada bagian penilaian supervisi dan setelah diadakan diskusi dengan guru, peneliti, dan supervisor sebagai berikut. Menyusun soal/perangkat penilaian sesuai dengan indikator/kriteria unjuk kerja yang telah ditentukan berjumlah 12 guru dengan persentasi $75 \%$. Masih 4 guru yang belum mampu menyusun soal 
penilaian karena masih tidak sesuai dengan indikatornya. Berdasarkan pengamatan/analisis ternyata guru tersebut belum paham betul pada kata kerja yang ada dalam indikator tersebut. Oleh sebab itu, guru-guru itu masih perlu belajar bersama tentang indikator tersebut.

Melaksanakan penilaian berjumlah 12 guru dengan persentasi $75 \%$. Masih ada guru yang membiarkan siswanya membuka buka dalam ulangan tersebut. Hal seperti ini akan merugikan anak. Bahkan penilaian itu tidak bisa digunakan untuk mengukur kemampuan siswa. Guru seperti ini perlu diberi bimbingan secara khusus tentang pentingnya penilaian. Memeriksa jawaban/memberikan skor tes hasil belajar berdasarkan indikator/kriteria unjuk kerja yang telah ditentukan berjumlah 12 guru dengan persentasi $75 \%$. Guru yang belum mampu memberikan skor, rata-rata guru yunior yang belum pernah mengikuti pelatihan. Skor dianggap sama dengan bobot. Untuk mengatasi seperti itu, guru-guru tersebut diikutkan KKG atau diberi bimbingan secara khusus. Menilai hasil belajar siswa berjumlah 16 guru dengan persentasi $100 \%$. Karena semua guru sudah mampu pada indikator ini dipertahankan. Mengolah hasil penilaian berjumlah 12 guru dengan persentasi $75 \%$. Guru yang belum mampu mengolah nilai sebagian besar sama dengan guru yang tidak paham terhadap penyekoran pembobotan nilai. Menganalisis hasil penilaian (berdasarkan tingkat kesukaran, daya pembeda, validitas dan reabilitas) berjumlah 10 guru dengan persentasi $62,5 \%$. Guru yang tidak bisa menganalisis soal rata-rata guru yang enggan menganalisis atau tidak mau menganalisis sehingga lupa cara menganalisis. Untuk menghadapi seperti itu, sekolah perlu mengadakan workshop di sekolah. Menyimpulkan hasil penilaian secara jelas dan logis (misalnya: interpretasi kecenderungan hasil penilaian, tingkat pencapaian siswa, dll) berjumlah 10 guru dengan persentasi $62,5 \%$. Karena tidak bisa menganalisis butir soal akibatnya guru tersebut tidak bisa menyimpulkan penilaian secara logis dan jelas. Untuk mengatasi hal itu, guru tersebut diajak diskusi atau diajak mengikuti workshop di sekolah. Menyusun laporan hasil penilaian berjumlah 10 guru dengan persentasi $62,5 \%$. Guru yang tidak bisa melaporkan hasil penilaian rata-rata guru tersebut malas membuat laporan. Karena seperti itu, maka kepala sekolah harus memotivasi terhadap guru bahwa betapa pentingnya membuat laporan penilaian. Memperbaiki soal/perangkat penilaian berjumlah 10 guru dengan persentasi $62,5 \%$. Guru yang tidak mampu memperbaiki soal yang jelek sebagian besar guru yang kurang paham terhadap indikator dalam kisi-kisi penilaian. Untuk mengatasi itu, guru tersebut diajak diskusi atau kerja kelompok. Rata-rata keberhasilan pada kompetensi ini adalah 54\% .

Refleksi Pelaksanaan Tindak Lanjut Penilaian Siklus I pada bagian ini dilakukan berdasarkan pada data yang dikumpulkan oleh supervisor dan dianalisis lalu dicarikan solusinya. Hasil refleksinya sebagai berikut. Mengidentifikasi kebutuhan tindak lanjut hasil penilaian berjumlah 8 guru, dengan persentasi 50\%. Pada bagian ini masih ada 8 guru yang belum mampu mengidentifikasikan kebutuhan tindak lanjut. Oleh sebab itu, pada siklus berikutnya guru tersebut diajak berdiskusi betapa pentingnya pelaksanaan tindak lanjut tersebut. Menyusun program tindak lanjut hasil penilaian berjumlah 8 guru, dengan persentasi $50 \%$ dari 16 guru. Guru yang belum mampu menyusun program tindak lanjut perlu melaksanakan bimbingan guru senior atau dengan dibimbing supervisor/guru senior guru tersebut menyusun program tindak lanjut. Melaksanakan tindak lanjut berjumlah 8 guru, dengan persentasi $50 \%$. Karena masih ada empat guru yang belum menyusun program, maka untuk mengatasi itu, supervisor/ guru senior memotivasi kepada guru tersebut supaya melaksanakan tindak lanjut.dengan bimbingan guru senior. Mengevaluasi hasil tindak lanjut hasil penilaian berjumlah 10 guru, dengan persentasi $62,5 \%$. Pelaksanaan ini belum dilakukan guru karena belum bisa membuat program makanya perlu motivasi pada guru tersebut, serta pendampingan. Menganalisis hasil evaluasi program tindak lanjut hasil penilaian berjumlah 10 guru dari 16 guru, dengan persentasi 62,5\%. Hasil analisis yang dilakukan guru masih sedikit. Untuk meningkatkan guru SD Negeri Dombo 1 Kecamatan Sayung agar mau menganalisis maka kepala sekolah/guru senior selalu memotivasi guru tersebut serta memberikan pendampingan.Pada kompetensi ini capaian guru adalah 54\% 
Secara lengkap hasil supervisi pada siklus I dapat dilihat pada tabel berikut ini:

Tabel 1. Hasil Supervisi Siklus I

\begin{tabular}{|c|l|c|}
\hline NO & \multicolumn{1}{|c|}{ INDIKATOR } & Keberhasilan \% \\
\hline 1 & Perencanaan Pembelajaran & 76 \\
\hline 2 & Melaksanakan Pembelajaran & 71 \\
\hline 3 & Menilai Prestasi Belajar & 54 \\
\hline 4 & Melaksanakan Tindak Lanjut & \\
\hline
\end{tabular}

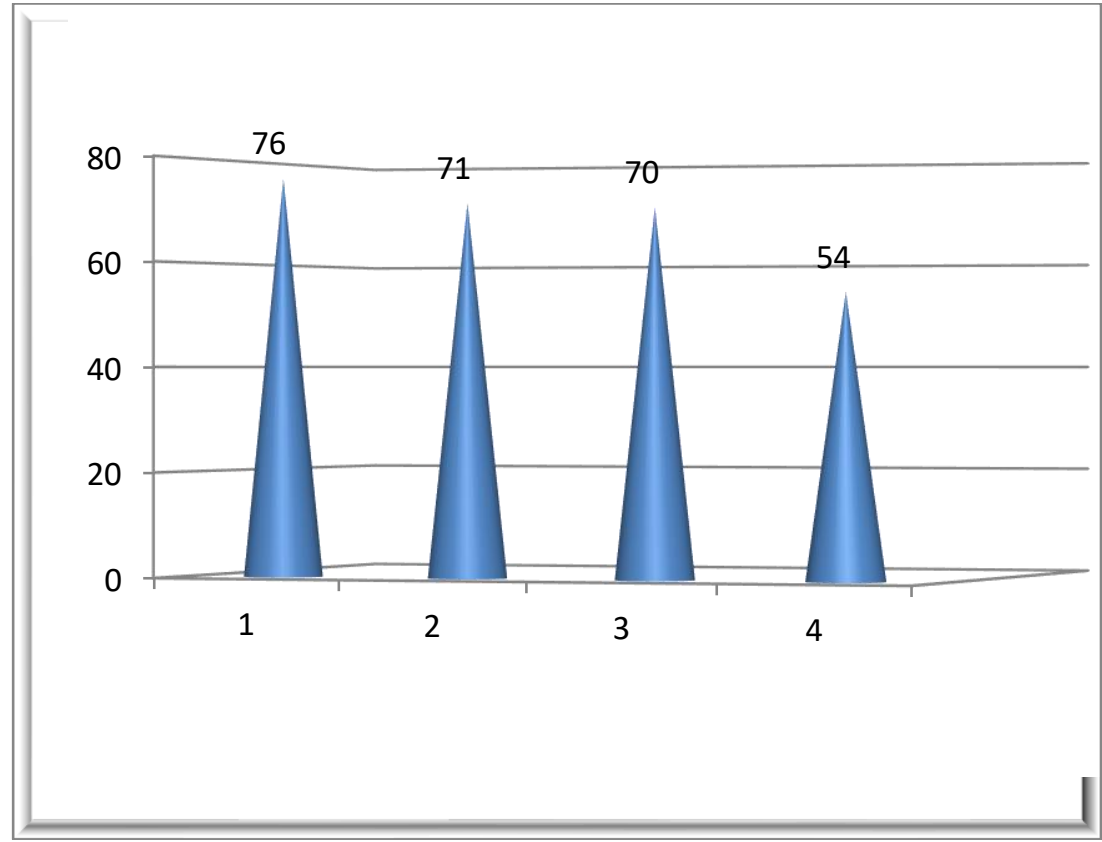

\section{Gambar 1. Hasil Supervisi Edukatif Siklus I}

\section{Keterangan:}

1. Perencanaan Pembelajaran

2. Melaksanakan Pembelajaran

3. Menilai Prestasi Belajar

4. Melaksanakan Tindak Lanjut

Hasil refleksi pada bagian pelaksanaan supervisi dan setelah diadakan diskusi dengan guru, peneliti, dan supervisor sebagai berikut. Supervisor memeberikan indikator yang harus dicapai pada saat persiapan, pelaksanaan, dan penilaian seminggu sebelum pelaksanaan supervisi, Supervisor menyuruh guru mengisi format penilaian yang ingin dicapai, satu minggu sebelum pelaksanaan supervisi, Supervisor mendiskusikan persiapan dengan guru yang akan disupervisi, Supervisor mengamati guru pada saat supervisi, Supervisor berdiskusi dengan guru setelah melaksanakan supervisi, Guru dan supervisor membuat perencanaan kembali kegiatan berikutnya yang akan disupervisi

Berdasarkan deskripsi dan refleksi di atas, peneliti melakukan tindak lanjut yang berkaitan dengan tindakan-tindakan yang perlu dilakukan pada siklus kedua, baik yang berkaitan dengan perencanaan, pelaksanaan, maupun penilaian.

Tindak Lanjut Perencanaan Supervisi Siklus I Guru yang disupervisi dan guru senior dibantu oleh supervisor membuat perencanaan pembelajaran yang kriterianya berdasarkan pada indikator yang telah dibuat oleh Dirjen Dikdasmmen dengan memperhatikan: Memperjelas tujuan pembelajaran yang ada dalam Kurikulum yang berlaku dengan membuat tujuan khusus 
pembelajaran Materi pembelajaran dibuat sesederhana mungkin dan urut dari yang sederhana ke yang sulit. Materi itu ditulis di RPP guru. Menentukan pembagian alokasi waktu secara spisifik dan berdasarkan pada langkah-langkah pembelajaran dan metodenya.Menentukan media pembelajaran secara kontekstual dan berdasarkan pada materi yang dipelajari siswa.Teknik penilaian didasarkan pada keterampilan atau materi yang diberikan.

Tindak Lanjut Pelaksanaan Supervisi Siklus I Pada siklus I pelaksanaan supervisi difokuskan pada kerja sama dalam pembelajaran di kelas. Guru senior membantu pada guru yunior dalam pembelajaran.Tindak Lanjut Penilaian Pembelajaran Siklus I Pada bagian penilaian ini guru berdiskusi dengan guru lain untuk menentukan penilaian yang cocok untuk pokok bahasan atau KD yang akan disampaikan pada siswa. Pelaksanaan Tindak Lanjut Penilaian Siklus I Pada bagian penilaian ini guru berdiskusi dengan guru lain untuk menentukan tindak lanjut penilaian karena banyak bagian yang belum dipahami oleh guru-guru SD Negeri Dombo 1. Untuk itu, ada beberapa rekomendasi yang perlu ditindaklanjuti pada siklus II yaitu: Para guru SD Negeri Dombo 1 Kecamatan Sayung perlu work shop tentang tindak lanjut penilaian, untuk membicarakan: identifikasi tindak lanjut hasil penilaian, menyusun program tindak lanjut, (c) Melaksanakan tindak lanjut, (d) mengevaluasi hasil tindak lanjut, menganalisis hasil evaluasi program tindak lanjut hasil penilaian.

Siklus II dilaksanakan berdasarkan temuan siklus I. Bagian yang sudah baik dipertahankan, sedangkan bagian yang persentasi keberhasilannya kecil diperbaiki pada siklus II ini. Berdasarkan refleksi dan pelaksanaan tindak lanjut siklus I, maka gambaran hasil dan temuan yang perlu ditindaklanjuti sebagai berikut. Perencanaan Supervisi Siklus II Guru berdiskusi dengan guru senior dan dibantu supervisor sekolah untuk merumuskan tujuan yang akan dicapai dalam pembelajaran. Tujuan itu bersumber pada KD / indikator atau pokok bahasan dan indikator kompetensi guru yang telah dirumuskan pada silabus. Hasil pembuatan perangkat tersebut dipahami bersama sebelum diberikan pada siswa.

Pembuatan format penilaian pra-KBM sebagai berikut. Mendeskripsikan tujuan pembelajaran Menentukan materi. Mengorganisasikan materi berdasarkan urutan dan kelompok Mengalokasikan waktu Menentukan metode pembelajaran yang sesuai dan diarahkan pada pembelajaran CTL.Merancang prosedur pembelajaran Menentukan media pembelajaran Menentukan sumber belajar yang sesuai Menentukan teknik penilaian

Pelaksanaan Supervisi Siklus II Instrumen penelitian pada siklus II tetap menggunakan instrumen yang dibuat oleh pemerintah. Menurut Dirjen Dikdasmen (2004: 8) instrumen tersebut berisi indikator sebagai berikut. Membuka pelajaran dengan metode yang sesuai Menyajikan materi pelajaran Menerapkan metode Mengatur kegiatan siswa di kelas Menggunakan media Menggunakan sumber belajar yang sesuai Memotivasi siswa Melakukan interaksi dengan siswa menggunakan bahasa yang komunikatif Memberikan pertanyaan dan umpan balik, untuk dan memperkuan penerimaan siswa dalam proses belajar Menyimpulkan pembelajaran Menggunakan waktu secara efektif dan efisien

Penilaian Supervisi Siklus II instrumen yang digunakan berdasarkan Dirjen Dikdasmen(2004: 11) yaitu: Menyusun soal penilaian sesuai dengan indikator unjuk kerja yang ditentukan Melaksanakan penilaian Memberikan skor tes hasil belajar berdasarkan kriteria unjuk kerja yang ditentukan Mengolah hasil penilaian Menganalisis hasil penilaian Menyimpulkan hasil penilaian secara jelas dan logis Menyusun laporan hasil penilaian Memperbaiki perangkat penilaian

Tindak Lanjut Hasil Penilaian Siklus II Kegiatan ini dilaksanakan oleh guru pada bagian terakhir. Adapun instrumen yang digunakan Dirjen Dikdasmen (2004: 12) yaitu: Mengidentifikasi kebutuhan tindak lanjut hasil penilaian Menyusun program tindak lanjut Melaksanakan tindak lanjut Mengevaluasi hasil tindak lanjut Menganalisis hasil evaluasi program tindak lanjut hasil penilaian

Tindakan Supervisor Siklus II Tindakan supervisor pada pelaksanaan supervisi siklus II sebagai berikut. Supervisor memeberikan indikator yang harus dicapai pada saat persiapan, pelaksanaan, dan penilaian seminggu sebelum pelaksanaan supervisi. Guru yang disupervisi 
diajak diskusi tentang format tersebut, Guru mengisi format penilaian yang ingin dicapai, satu minggu sebelum pelaksanaan supervisi, Supervisor berdiskusi dengan guru yang akan disupervisi, Supervisor mengamati guru pada saat supervisi dengan cara berkolaborasi secara langsung dalam PBM, Supervisor berdiskusi dengan guru setelah supervisi, Guru dan supervisor menganalis hasil belajar siswa dan membuat laporan bersama tentang pembelajaran. Guru dan supervisor menganalisis program yang telah dibuat untuk diperbaiki jika kurang sesuasi.

Refleksi Siklus II Perencanaan Pembelajaran Supervisi Siklus IISetelah berdiskusi dengan guru dan supervisor maka peneliti menulis hasil refleksi sebagai berikut. Mendeskripsikan tujuan pembelajaran 16 guru dengan presentasi $100 \%$, berdasarkan data tersebut sudah mampu mendeskripsikan tujuan pembelajaran. Untuk itu, model seperti ini tetap dipertahankan. Menentukan materi sesuai dengan kompetensi yang telah ditentukan sebanyak 16 guru dengan presentasi $100 \%$. Ternyata guru sudah mampu menentukan materi pembelajaran yang sesuai dengan kompetensinya. Guru lebih mudah menjalankan tugasnya jika supervisi edukatif dilakukan. Mengorganisasikan materi berdasarkan urutan dan kelompok sebanyak 14 guru dengan presentasi 87,5\%. Pada bagian ini guru yang mampu mengorganisasikan materi baik yang berupa materi konsep, perinsip, prosedur, maupun fakta. Ada satu guru yang skornya masih di bawah 80. Untuk memperbaiki keenam guru itu perlu dilakukan diskusi kembali dengan satu guru tersebut. Mengalokasikan waktu sebanyak 14 guru dari 16 guru dengan presentasi 87,5\% kategori baik. Kegiatan pada bagian ini dipertahankan karena satu guru masih belum mampu mengalokasikan waktu dengan tepat, tetapi nanti dibimbingnguru senior. Menentukan metode pembelajaran yang sesuai sebanyak 16 guru dengan presentasi $100 \%$ kategori sangat baik. Guru sudah semua melaksanakan metode pembelajaran yang mengarah student center. Hal seperti ini perlu dipertahankan. Guru kelas dan guru mata pelajaran, serta guru senior perlu berkolaborasi dalam mengajarnya lalu membahasnya melalui diskusi di KKG supaya menjadi contoh guru sekolah lain. Merancang prosedur pembelajaran sebanyak 12 guru dengan presentasi 75\%.kategori baik. Pada penentuan prosedur sangat berkaitan dengan metode pembelajaran. Oleh sebab itu, perlu ada perbaikan di bidang ini. Ada 4 guru masih belum mampu merancang prosedur pembelajaran perlu dibina dan diberikan motivasi.Menentukan media pembelajaran/peralatan praktikum (dan bahan) yang akan digunakan sebanyak 14 guru dengan presentasi 87,5\%. Ternyata pada bagian ini sudah banyak guru yang menggunakan media yang ada di sekitar kelas. Menentukan sumber belajar yang sesuai sebanyak 16 guru dengan presentasi 100\%. Dalam menentukan sumber belajar, guru sudah bervariatif. Itu pun sudah bisa menyesuaikan dengan kompetensi dasar yang harus dikuasai siswa. Menentukan teknik penilaian sebanyak 16 guru dengan presentasi $100 \%$. Teknik-teknik yang dibuat guru dalam menyusun penilaian sudah beragam. Ada yang menggunakan portofolio, kinerja, proyek, kuis, psikomotorik.

Refleksi Pelaksanaan Pembelajaran hasil Supervisi Siklus II Hasil refleksi pada bagian pelaksanaan supervisi dan setelah diadakan diskusi dengan guru, peneliti, dan supervisor sebagai berikut. Membuka pelajaran dengan metode yang sesuai. Guru rata-rata sudah mampu membuka pelajaran dengan metode yang tepat. Guru yang dianggap mampu membuka pekajaran dengan tepat sebanyak 14 orang guru dari 16 guru atau dengan persentasi 87,5\% (kategori baik). Berdasarkan persentasi di atas, guru perlu mempertahankan cara tersebut. Menyajikan materi pelajaran. Dalam menyajikan materi pelajaran, guru rata-rata sudah baik dan berdasarkan pengamatan ada 14 guru yang dikategorikan baik. Jika hal itu dipersentasi maka sudah mencapai $87,5 \%$ (kategori baik) Pada siklus II ini guru banyak yang sudah mempu menyajikan materi dengan urutan yang tepat. Untuk itu, model penguasaan materi dalam supervisi edukatif perlu dipertahankan. Menerapkan metode dan prosedur pembelajaran yang telah ditentukan berjumlah 16 guru dengan persentasi $100 \%$. Guru dalam menggunakan metode pembelajaran semua sudah mengarah ke model CTL (pembelajaran contectual).Mengatur kegiatan siswa di kelas berjumlah 16 guru dengan persentasi $100 \%$. Berdasarkan data tersebut guru sudah mampu mengelola kelas. Pelu dipertahankan. 
Menggunakan media pembelajaran/peralatan praktikum (dan bahan) yang telah ditentukan berjumlah 16 guru dengan persentasi $100 \%$. Guru banyak menggunakan media yang bisa menguatkan pembelajaran. Menggunakan sumber belajar yang telah dipilih (berupa buku, modul, program komputer dan sejenisnya) berjumlah 16 guru dengan persentasi $100 \%$. Pada bagian ini guru sudah tidak masalah lagi. Tetapi, kepala sekolah, supervisor harus terus memotivasi guru-guru tersebut untuk terus menggunakan buku sumber.

Memotivasi siswa dengan berbagai cara yang positif, berjumlah 16 guru dengan persentasi $100 \%$. Guru sudah memotivasi siswa. Kegiatan seperti ini perlu dipertahankan Melakukan interaksi dengan siswa menggunakan bahasa yang komunikatif berjumlah 14 guru dengan persentasi $87,5 \%$. Ada satu guru yang masih menggunakan bahasa yang sulit dipahami siswa.. Memberikan pertanyaan dan umpan balik, untuk mengetahui dan memperkuan penerimaan siswa dalam proses belajar berjumlah 14 guru dengan persentasi 87,5\% kategori baik. Guru yang memberikan pertanyaan-pertanyaan sebagai umpan balik ternyata sudah banyak. Hal ini dikarenakan ada kerja sama antara guru yang disupervisi dengan supervisornya. Menyimpulkan pembelajaran berjumlah 14 guru dengan persentasi 87,5\% kategori baik. Setelah siklus II dilaksanakan, kemudian guru dan supervisor berdiskusi tentang cara menyimpulkan pembelajaran ternyata membawa hasil yang memuaskan Menggunakan waktu secara efektif dan efisien berjumlah 14 guru dengan persentasi 87,5\%. Kategori baik. Pada siklus II ternyata 14 guru dapat memanfaatkan waktu secara efektif dan efisien. Yang satu guru diminta belajar dengan guru senior.Pada Kompetensi ini capaian rata-rata adalah: 89\%

Refleksi Penilaian Supervisi Siklus II Hasil refleksi pada bagian penilaian supervisi dan setelah diadakan diskusi dengan guru, peneliti, dan supervisor sebagai berikut. Menyusun soal/perangkat penilaian sesuai dengan indikator/kriteria unjuk kerja yang telah ditentukan berjumlah 14 guru dengan persentasi $75 \%$. Masih ada dua guru yang belum mampu menyusun soal penilaian karena masih tidak sesuai dengan indikatornya. Berdasarkan pengamatan/analisis ternyata guru tersebut pada pertemuan dengan supervisor tidak mmemperhatikan penjelasan dan tidak mau bertanya bahkan cenderung acuh..

Melaksanakan penilaian berjumlah 12 guru dengan persentasi $75 \%$. Hampir semua guru sudah melaksanakan penilaian sesuai dengan aturan. Siswa tidak boleh membuka, bertanya kepada siswa lain. Hal seperti ini perlu dilakukan karena peneilaian itu untuk mengukur anak yang sudah mampu atau yang belum mampu, tetapi masih ada dua guru yang membiarkan siswanya mebuka catatan. Memeriksa jawaban/memberikan skor tes hasil belajar berdasarkan indikator/kriteria unjuk kerja yang telah ditentukan berjumlah 14 guru dengan persentasi $87,5 \%$. Guru sudah mampu memberikan skor soal. Cara seperti yang sudah dilakukan perlu dipertahankan. Mengolah hasil penilaian berjumlah 16 guru dengan persentasi $100 \%$. Guru sudah mampu mengolah nilai mulai dari penskoran pembobotan sampai pada memberi nilai siswa. Menganalisis hasil penilaian (berdasarkan tingkat kesukaran, daya pembeda, validitas dan reabilitas) berjumlah 12 guru dengan persentasi 75. Menyimpulkan hasil penilaian secara jelas dan logis berjumlah 12 guru dengan persentasi $75 \%$ Menyusun laporan hasil penilaian berjumlah 12 guru dengan persentasi 75\%. Memperbaiki perangkat penilaian berjumlah 16 guru dengan persentasi $100 \%$. Semua guru pada siklus II ini sudah bisa memperbaiki soal yang kurang valid. Makanya guru tetap mempertahankan cara memperbaiki soal tersebut. Hasil kegiatan capaian indikator pada kompetensi ini adalah: 90\%

Refleksi Pelaksanaan Tindak Lanjut Penilaian Siklus II Refleksi pada bagian tindak lanjut ini dilakukan berdasarkan pada data yang dikumpulkan oleh supervisor dan dianalisis lalu dicarikan solosinya. Hasil refleksinya sebagai berikut. Mengidentifikasi kebutuhan tindak lanjut hasil penilaian berjumlah 12 guru, dengan persentasi $75 \%$. Pada siklus II perkembangan guru pesat sekali karena tinggal 4 guru saja yang belum mencapai skor 70 . Menyusun program tindak lanjut hasil penilaian berjumlah 12 guru, dengan persentasi $75 \%$.

Melaksanakan tindak lanjut berjumlah 6 guru, dengan persentasi $75 \%$. Guru SD Negeri Dombo 1 Kecamatan Sayung sudah banyak melaksankan tindak lanjut penilaian. Ini terbukti 12 guru telah melaksanakan dengan baik, sedangkan 4 guru sudah melaksanakan tindak lanjut 
tetapi skor yang dicapai masih di bawah 70 Mengevaluasi hasil tindak lanjut hasil penilaian berjumlah 14 guru, dengan persentasi 87,5 \%. Karena siklus II ini guru sudah mampu mengevaluasi hasil tindak lanjut maka tindakan guru tersebut perlu dipertahankan. Menganalisis hasil evaluasi program tindak lanjut hasil penilaian berjumlah 16 guru, dengan persentasi $100 \%$. Semua guru sudah menganalisis hasil evaluasi program tindak lanjut penilaian. Pada kompetensi ini rata-rata capaian guru $84 \%$

Refleksi Tindakan Supervisor Siklus II Hasil refleksi pada bagian pelaksanaan supervisi dan setelah diadakan diskusi dengan guru, peneliti, dan supervisor sebagai berikut. Supervisor memeberikan indikator yang harus dicapai pada saat persiapan, pelaksanaan, dan penilaian seminggu sebelum pelaksanaan supervisi Guru mengisi format penilaian yang ingin dicapai, satu minggu sebelum pelaksanaan supervisi. Supervisor persiapan dengan guru yang akan disupervisi, mengamati guru pada saat supervisi, berdiskusi dengan guru setelah melaksanakan supervisi, Guru dan supervisor membuat tindak lanjut program penilaian
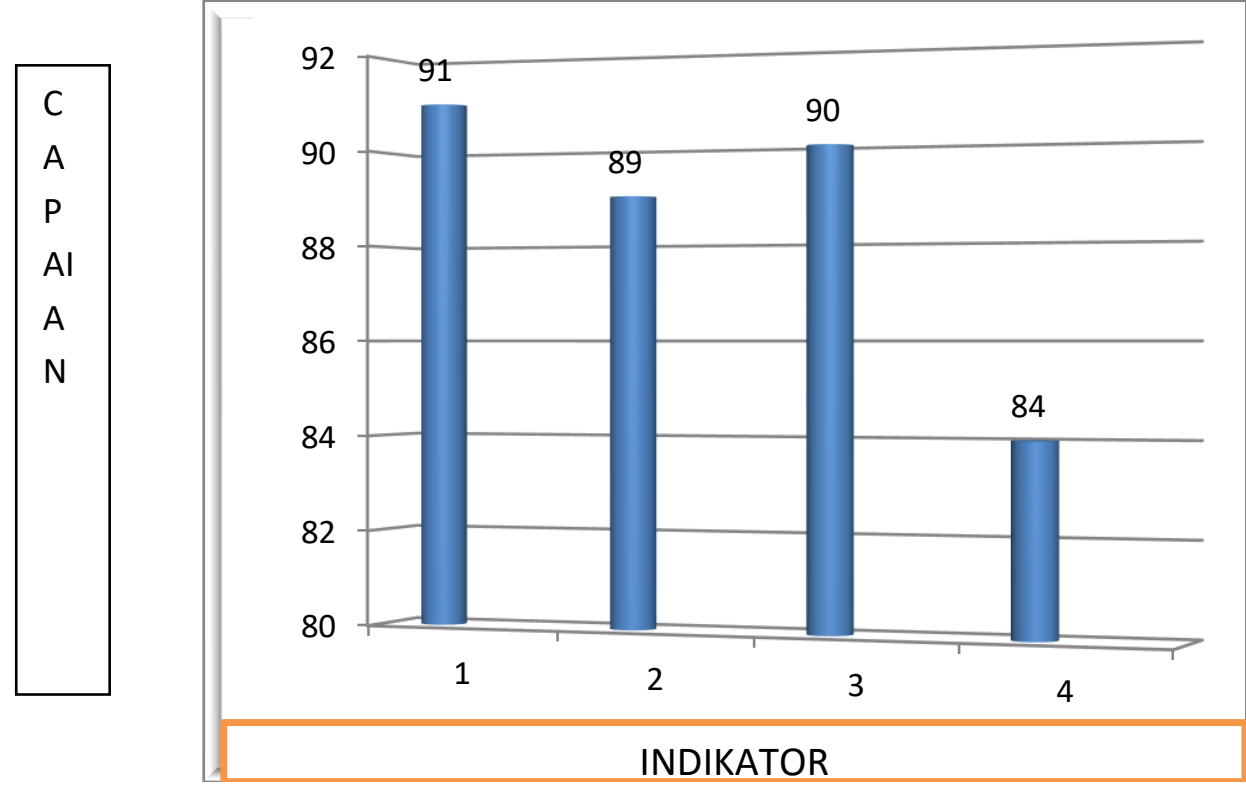

Gambar 2. Rangkuman Hasil Supervisi Edukatif Siklus II

Hasil Tindakan Penelitian Siklus II Berdasarkan deskripsi dan refleksi di atas, peneliti, guru dan supervisor menghentikan penelitian tindakan ini karena hasil yang diperoleh setelah tindakan, baik yang dilakukan oleh guru, supervisor, maupun guru senior sudah memuaskan. Tindakan-tindakan supervisor yang dapat meningkatkan hasil supervisi guru sebagai berikut.Perencanaan Supervisi meliputi: Guru dan supervisor bekerja sama dalam membuat persiapan supervisi, termasuk menentukan instrumen penilaian, pelaksanaan, dan penilaian hasil siswa, guru diberi format penilaian selalu menanyakan kekurangmampuan dan kekurang jelasan format penilaian tersebut, menanyakan perangkat pembelajaran berkaitan dengan pembelajaran maupun penilaian.Pelaksanaan Supervisi Guru dan supervisor bekerja sama melaksanakan pembelajaran, membuka pelajaran dengan apersepsi dan menggunakan skema siswa, kemudian dilanjutkan oleh guru yang disupervisi.Dalam pelaksanaan supervisi, guru merasa nyaman pada saat mengajarnya karena supervisor dalam mensupervisi seperti rekanan guru yang mengajar bersama di kelas, mengamati guru yang sedang mengajar dengan catatancatatan khusus tentang kejadian positif dan negatif pada pembelajaran itu Guru memberi penilaian proses dengan berdasarkan persiapan yang dikerjakan dengan guru senior atau supervisor berdiskusikan kelebihan dan kekurangan pembelajaran.

Penilaian Supervisi berdasarkan program yang sudah dibuat. Penilaian difokuskan pada bentuk uraian objektif dan uraian non-objektif. Penyusunan soal dilaksanakan secara kolaboratif dengan guru senior / supervisor Pengoreksian hasil evaluasi dilakukan secara langsung oleh guru setelah pembelajaran. Hal seperti itu dilakukan dengan guru senior. Guru memnyimpulkan hasil belajar siswa dan melaporkan hasilnya kepada kepala sekolah. 
Tindak Lanjut Hasil Penelitian Guru dan supervisor menindak lanjuti hasil penilaian dengan langkah-langkah: Guru mengumpulkan hasil penilaian ,mendiskusikan tindak lanjut penilaian, merencanakan tindak lanjut hasil penilaian , bersama supervisor mengevaluasi hasil tindak lanjut penilaian kemudian menganalisisnya .

Hasil Tindakan Supervisor dalam pelaksanaan supervisi dan setelah diadakan diskusi dengan guru, peneliti, dan supervisor sebagai berikut, memeberikan indikator yang harus dicapai pada saat persiapan, pelaksanaan, dan penilaian seminggu sebelum pelaksanaan supervisi, menyuruh guru mengisi format penilaian yang ingin dicapai, satu minggu sebelum pelaksanaan supervisi, mendiskusikan persiapan dengan guru yang akan disupervisi, mengamati guru pada saat supervisi, berdiskusi dengan guru setelah melaksanakan supervisi, Guru dan supervisor membuat perencanaan kembali kegiatan berikutnya yang akan disupervisi

\section{Pembahasan}

Berdasarkan hasil penelitan di atas, peneliti membahasnya dari segi pengalaman peneliti pada saat menjadi supervisor pada guru SD Negeri Dombo 1 karena diberi tugas mensupervisi para guru tersebut. Selain itu, pembahasan didasarkan pada teori-teori yang sudah ada, baik berdasarkan pada referensi mapun dari pendapat ahli di bidang penelitian ini.

Adapun pembahasan hasil penelitian ini sebagai berikut.

Temuan pertama, kinerja guru meningkat dalam membuat perencanaan pembelajaran. Hal ini terjadi karena adanya kerja sama antara guru mata pelajaran yang satu dengan lainnya dengan dibantu oleh guru senior yang ditugasi oleh kepala sekolah untuk mensupervisi guru tersebut. Langkah-langkah yang dapat meningkatkan kinerja guru dalam membuat persiapan pembelajaran adalah: (1) Guru senior/supervisor memberikan format supervisi dan jadwal supervisi pada awal tahun pelajaran atau awal semester.

Supervisi merupakn salah satu tugas dari seorang Kepala Sekolah selaku supervisor di satuan pendidikan tertentu. Supervisi adalah suatu aktivitas pembinaan yang direncanakan untuk membantu para guru dan pegawai sekolah lainnya dalam melakukan pekerjaan mereka secara efektif (Purwanto, 2003:32)

Menurut Jones dalam Mulyasa (2003:155), supervisi merupakan bagian yang tidak terpisahkan dari seluruh proses administrasi pendidikan yang ditujukan terutama untuk mengembangkan efektivitas kinerja personalia sekolah yang berhubungan tugas-tugas utama pendidikan. Menurut carter, supervisi adalah usaha dari petugas-petugas sekolah dalam memimpin guru-guru dan petugas-petugas lainnya dalam memperbaiki pengajaran, termasuk menstimulasi perkembangan guru serta merevisi tujuan-tujuan pendidikan, bahan pengajaran, metode dan evaluasi pengajaran (Sahertian, 2000:17)

Supervisi edukatif merupakan supervisi yang diarahkan pada kurikulum pembelajaran, proses belajar mengajar, pelaksanaan bimbingan dan konseling. Supervisi ini dapat dilakukan oleh pengawas, kepala sekolah, maupun guru senior yang sudah pernah menjadi instruktur mata pelajaran. Menurut Dirjen Dikdasmmen (1984:15)

Jadi supervisi yang merupakan bagian dari tugas kepala sekolah adalah upaya seorang kepala sekolah dalam pembinaan guru agar guru dapat meningkatkan kualitas mengajarnya dengan melalui langkah-langkah perencanaan, penampilan mengajar yang nyata serta mengadakan perubahan dengan cara yang rasional dalam usaha meningkatkan hasil belajar siswa

Pelaksanaan supervisi tidak hanya dilakukan sekali, (2) Guru senior selalu menanyakan perkembangan pembuatan perangkat pembelajaran (mengingatkan betapa pentingnya perangkat pembelajaran), (3) satu minggu sebelum pelaksanaan supervisi perangkat pembelajaran, supervisor/guru senior menanyakan format penilaian, jika format yang diberikan pada awal tahun pelajaran tersebut hilang, maka guru yang bersangkutan disuruh memfotokopi arsip sekolah. Jika di sekolah masih banyak format seperti itu maka guru tersebut diberi kembali. Bersamaan dengan memberi/menanyakan format, supervisor meminta pengumpulan perangkat pembelajaran yang sudah dibuatnya untuk untuk diteliti kelebihan dan 
kekurangannya, (4) Supervisor memberikan catatan-catatan khusus pada lembaran untuk diberikan kepada guru yang akan disupervisi tersebut. (5) Supervisor dalam menilai perangkat pembelajaran penuh perhatian dan tidak mencerminkan sebagai penilai. Supervisor bertindak sebagai kolaborasi. Supervisor membimbing, mengarahkan guru yang belum bisa, tetapi supervisor juga menerima argumen guru yang positif. Dengan adanya itu, terciptalah hubungan yang akrap antara guru dan supervisor. Tentu saja ini akan membawa nilai positif dalam pelaksanaan pembelajaran.

Temuan kedua, kinerja guru meningkat dalam melaksanakan pembelajaran. Dalam penelitian tindakan ini ternyata dari tiga puluh satu guru hampir semuanya mampu melaksanakan pembelajaran dengan baik. Hal ini terbukti dari hasil supervisi. Langkah-langkah yang dilakukan untuk meningkatkan pelaksanaan pembelajaran berdasarkan penelitian tindakan ini adalah: (1) Supervisor yang mengamati guru mengajar tidak sebagai penilaia tetapi sebagai rekan bekerja yang siap membantu guru tersebut, (2) Selama pelaksaaan supervisi di kelas guru tidak menganggap supervisor sebagai penilai karena sebelum pelaksanaan supervisi guru dan supervisor telah berdiskusi permasalahan-permasalahan yang ada dalam pembelajaran tersebut, (3) Supervisor mencatat semua peristiwa yang terjadi di dalam pembelajaran baik yang positif maupun yang negatif, (4) Supervisor selalu memberi contoh pembelajaran yang berorientasi pada Modern Learning. (5) Jika ada guru yang pembelajarannya kurang jelas tujuan, penyajian, umpan balik, supervisor memberikan contoh bagaimana menjelaskan tujuan, menyajikan, memberi umpan balik kepada guru tersebut, (6) Setelah guru diberi contoh pembelajaran modern, Supervisor setiap dua atau tiga minggu mengunjungi atau mengikuti guru tersebut dalam proses pembelajaran.

Karena setiap guru bertanggungjawab terhadap mutu pembelajaran untuk setiap mata

pelajaran yang diampunya agar peserta didik mampu : (a)meningkat rasa ingin tahunya ,(b) men capai keberhasilan belajarnya secara konsisten sesuai dengan tujuan pendidikan( c) memahami perkembengan pengetahuan dengan kemampuan mencari informasi.(d) mengolah informasi menjadi pengetahuan (e) menggunakan pengetahuan untuk menyelesaikan masalah(f) mengkomunikasikan pengetahuan pada pihak lain (g) mengembangkan belajar mandiri dan kelompok secara wajar .Apalagi evaluasi pendayagunaan pendidik dan tenaga kependidikan itu meliputi kesesuaian penugasan dengan keahlian, keseimbangan beban kerja dan kinerja pendidik dan tenaga kependidikan dalam pelaksanaan tugas. Sedangkan kepala Sekolah bertanggung jawab terhadap kegiatan Pembelajaran sesuai dengan peraturan yang telah ditetapkan oleh pemerintah ( BSNP 2007: 16)

Sekolah juga harus mendokumentasikan dan menggunakan hasil pemantauan, supervisi,evaluasi dan pelaporan serta catatan tindak lanjut untuk memperbaiki kinerja sekolah dalam pengelolaan pembelajaran dan pengelolaan secara keseluruhan disekolah tersebut (BNSP $2007: 33$ ).

Temuan ketiga, kinerja guru meningkat dalam menilai prestasi belajar siswa. Pada penelitian tindakan yang dilakukan di SD Negeri Dombo 1 Kecamatan Sayung ini ternyata pelaksanaan supervisi edukatif memberikan dampak positif terhadap guru dalam menyusun soal/perangkat penilaian, melaksanakan, memeriksa, menilai, mengolah, menganalisis, menyimpulkan, menyusun laporan dan memperbaiki soal. Sebelum diadakan supervisi edukatif secara kolaboratif, guru banyak yang mengalami kesulitan dalam melaksankan penilaian. Langkah-langkah yang dilakukan dalam supervisi edukatif kolaboratif secara periodik yang dapat meningkatkan kinerja guru adalah: (1) Supervisor berdiskusi dengan guru dalam pembuatan perangkat penilaian sebelum dilaksanakan supervisi, (2) Guru melaksnakan penilaian sesuai dengan aturan yang telah ditetapkan bersama supervisor yang sebagai kolaboratif dalam pembelajaran, (3) Guru membuat kriteria penilaian yang berkaitan dengan penskoran, pembobotan, dan pengolahan nilai, yang sebelum pelaksanaan supervisi didiskusikan dengan supervosor, (4) Guru menganalisis hasil penilaian dan melaorkannya kepada urusan kurikulum. 
Temuan keempat, Kinerja guru meningkat dalam melaksanakan tindak lanjut hasil penilaian prestasi belajar peserta didik. Langkah-langkah yang dapat meningkatkan kinerja guru dalam supervisi edukatif adalah: (1) Supervisor dan guru bersama-sama membuat program tindak lanjut hasil penilaian, (2) Guru senior/supervisor memberi contoh pelaksanaan tindak lanjut, yang akhirnya dilanjutkan oleh guru dalam pelaksanaan yang sebenarnya, (3) Supervisor atau guru senior mengajak diskusi pada guru yang telah membuat, melaksanakan, dan menganalis program tindak lanjut.

Temuan kelima, Kinerja guru meningkat dalam menyusun program pembelajaran, melaksanakan pembelajaran, menilai prestasi belajar, dan melaksanakan tindak lanjut hasil prestasi belajar siswa ternyata membawa kenaikan prestasi siswa dalam belajar.

Tabel 2. Perbandingan Hasil Supervisi Siklus I Dan II

\begin{tabular}{|c|l|c|c|}
\hline \multirow{2}{*}{ NO } & \multicolumn{1}{|c|}{ INDIKATOR } & \multicolumn{2}{|c|}{ \%Ke keberhasilan } \\
\cline { 3 - 4 } & & Siklus I & Siklus II \\
\hline 1 & Perencanaan Pembelajaran & 76 & 91 \\
\hline 2 & Melaksanakan Pembelajaran & 71 & 89 \\
\hline 3 & Menilai Prestasi Belajar & 70 & 90 \\
\hline 4 & Melaksanakan Tindak Lanjut & 54 & 84 \\
\hline
\end{tabular}

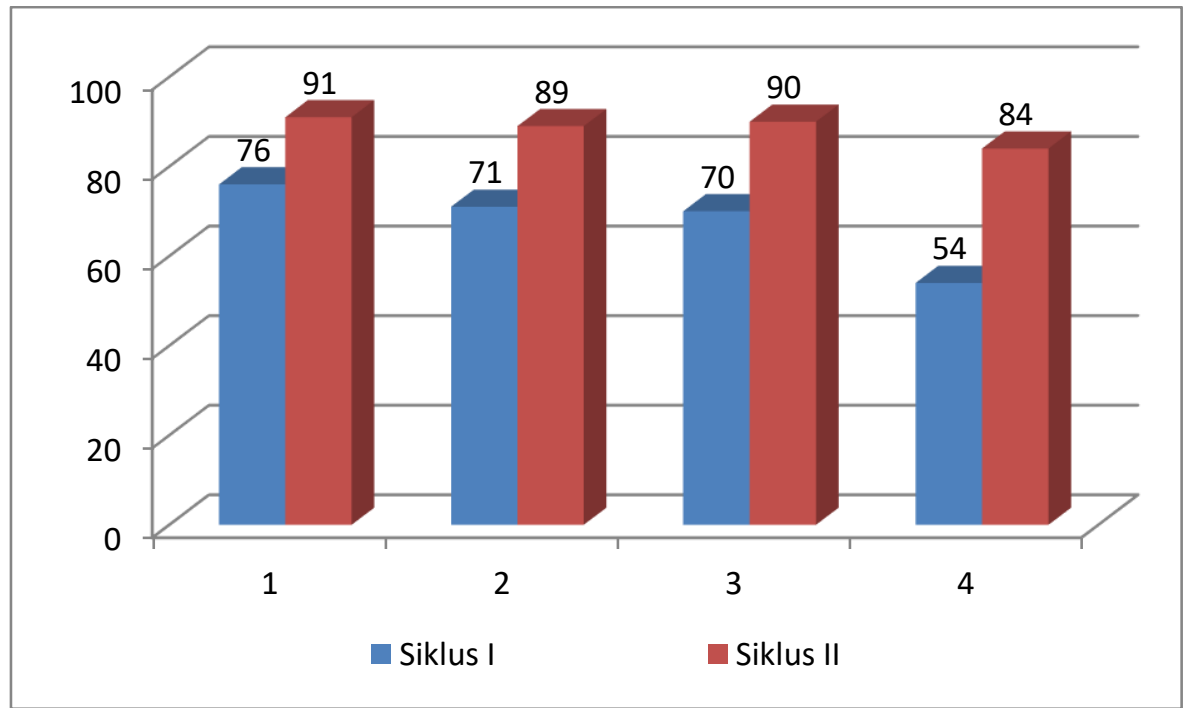

Gambar 3. Perbandingan Hasil Supervisi Siklus I Dan II

\section{KESIMPULAN}

Hasil penelitian menunjukkan bahwa kinerja guru meningkat setelah dilakukan tindakan yang berupa supervisi edukatif secara langsung dari siklus I ke siklus II. Peningkatan tersebut meliputi peningkatan dalam menyusun rencana pembelajaran, melaksanakan pembelajaran, menilai prestasi belajar, melaksanakan tindak lanjut penilaian prestasi belajar siswa Berdasarkan hasil supervisi edukatif siklus I dan siklus II kinerja guru meningkat, yakni siklus I Kinerja guru dalam menyusun rencana pembelajaran siklus I mencapai $76 \%$ sedangkan siklus II $91 \%$. Kinerja guru dalam melaksanakan pembelajaran siklus I mencapai $71 \%$ sedangkan siklus II mencapai $89 \%$. Kinerja guru dalam menilai prestasi belajar siklus I mencapai $70 \%$ sedangkan siklus II $90 \%$. Kinerja guru dalam melaksanakan tindak lanjut penilaian prestasi 
belajar siswa pada siklus I mencapai $54 \%$ sedangkan siklus II $84 \%$. Dengan demikian tindakan siklus II rata-rata sudah di atas $75 \%$.

Berdasarkan hasil penelitian tindakan tersebut dapat disimpulkan bahwa kinerja guru SD Negeri Dombo 1 Kecamatan Sayung Kabupaten Demak pada semester I Tahun Pelajaran 2021 / 2022, meningkat dalam menyusun rencana pembelajaran, melaksanakan pembelajaran, menilai prestasi belajar, melaksanakan tindak lanjut penilaian prestasi belajar siswa melalui supervisi edukative Untuk itu, peneliti menyarankan agar supervisi edukatif di sekolah-sekolah melaksanakan supervisi edukatif .

\section{DAFTAR PUSTAKA}

Arikunto S, 2006, Penelitian Tindakan Kelas. Jakarta: Bumi Aksara.

Arikunto, Suharsimi. 2010. Prosedur Penelitian: Suatu Pendekatan Praktik. Jakarta: Rineka Cipta

Badan Standar Nasional Pendidikan (BSNP). 2007.Peraturan Menteri Pendidikan Nasional Republik Indoesia No 19 Tahun 2007 Tentang Stándar Pendidikan Nasional Jakarta BSNP

Depdiknas.2005. Peraturan pemerintah Nomor 19 Tahun 2005 tentang Standar Nasional Pendidikan ,Jakarta

Endang Mulyaningsih. 2011. Riset Terapan Bidang Pendidikan dan Teknik. Yogyakarta: UNY Pres

Husaini Usman. 2014. Manajemen Reori, Praktik, dan Riset Pendidikan. Bandung: Bumi Aksara.

Ibrahim Bafadal. 2012. Manajemen Peningkatan Mutu Sekolah Dasar. Jakarta: Bumi Akasara.

Karnadi. 2003. Undang-Undang Republik Indonesia Nomor 20 Tahun 2003, tentang Sistem Pendidikan Nasional. Jakarta : BP. Cipta Jaya

Kementerian Pendidikan Nasional. 2010. Pengembangan Pendidikan Budaya dan Karakter Bangsa. Jakarta: Puskur.

Moleong, Lexy. J. 2001. Metodologi Penelitian Kualitatif. Bandung: Penerbit PT. Remaja Rosdakarya.

Mulyani. 2010. Model Integrasi Tindak Tutur Direktif dalam Penerapan Pendidikan Ahlaq Mulia dan Karakter Bangsa Bagi Pelajar di SMA. Jurnal Penelitian Inovasi dan Perekayasa Pendidikan, No. 2 tahun ke 1, Agustus 2010. Halaman 225-248. Puslit jak nov, Balitbang Kemendiknas.

Mulyasa, E. 2003. Manajemen Berbasis Sekolah. Konsep, Strategi dan Implementasi, Bandung: Rosda Karya.

Pidarta, I Made.1980. Perencana Pendidikan Dengan Pendekatan Sistim. Jakarta: Rineke Cipta.

Purwanto, Ngalim.1988, Administrasi dan Supervisi Pendidikan. Bandung Remaja Karya.

Soegito,AT.2013. Pergeseran Paradikmatik Manajemen Pendidikan. Semarang: Universitas Negeri semarang.

Wahjosumijo. 2004. Kinerja Kepala sekolah. Bandung: Rineke Cipta 